\section{Effect of Manganese Source on Manganese Uptake by Pygmy Date Palms}

\author{
Timothy K. Broschat \\ University of Florida, Fort Lauderdale Research and Education Center, \\ 3205 College Avenue, Fort Lauderdale, FL 33314
}

Additional index work. Phoenix roebelenii, micronutrient fertilizers

Abstract. Pygmy date palms (Phoenix roebelenii 'O'Brien') growing in a pine barkCanadian peat-sand container medium and in a sandy field soil were fertilized with one of five commercially available Mn sources. Fertilization with Mn sulfate plus ammonium sulfate consistently increased Mn uptake above that of control palms. Four soluble Mn sources were applied to the foliage of container-grown palms, but only Mu sulfate consistently increased Mn concentrations in the leaves. Addition of urea, calcium hydroxide, or dimethylsulfozide did not improve Mn uptake from foliar sprays, and foliar sprays and soil applications were equally rapid in their effects on leaf Mn concentration.

Manganese deficiency is a serious and widespread problem on many species of palms (Eroschat, 1991). Recommended treatments for correction or prevention of the problem usually include soil or foliar applications of manganese sulfate (Dickey, 1977), but Broschat and Donselman (1985a) found that in a peat-based potting medium, other Mn sources provided equivalent levels of ammonium acetate-extractable $\mathrm{Mn}$.

Addition of urea to foliar Mn sprays increased foliar absorption of $\mathrm{Mn}$ in some plants (Labanauskas and Puffer, 1964; Yamada et al., 1965), but, to our knowledge, this has never been shown for palms. A foliar spray of $\mathrm{Mn}$ sulfate plus calcium hydroxide is recommended by Dickey (1977) for treatment of Mn deficiency, but the value of the added $\mathrm{Ca}$ in palm treatment is not known. Dimethylsulfoxide (DMSO) is a widely used penetrant-solvent that could potentially enhance foliar absorption of Mn from foliar sprays, but, to our knowledge, has never been tested. Several Mn fertilizer sources have been evaluated on field crops (Fiskel and Mourkides, 1955; Randall et al., 1975; Shuman et al., 1979; Wilcox and Cantliffe, 1969), but none of these studies evaluated Mn fertilizers in a container medium or tested foliar fertilization effectiveness on palms. Similarly, soil acidification has been suggested as a means of alleviating deficiencies of micronutrients, such as Mn, Fe, and Zn (Kidder et al., 1990; Messenger and Hruby, 1990), but this has not been tested on palms. The purpose of this study was to determine which of the commercially available soil and foliar-applied Mn fertilizer materials are effective in supplying Mn to palms in a pine bark-peat-

Received for publication 25 Feb. 1991. Florida Agricultural Experiment Station Journal Series no. R-01264. The cost of publishing this paper was defrayed in part by the payment of page charges. Under postal regulations, this paper therefore must be hereby marked advertisement solely to indicate this fact. sand medium and if the addition of calcium hydroxide, urea, or DMSO enhanced the foliar absorption of Mn from foliar sprays.

Pygmy date palms, 25 to $30 \mathrm{~cm}$ tall, were planted in lo-liter plastic containers using a 4 pine bark : 2 Canadian peat : 1 sand (by volume) medium amended with dolomite at $6 \mathrm{~kg} \cdot \mathrm{m}^{-3}$. Eight replicate pots were each treated on 14 Oct. 1987 (first year) with single applications of the materials to the surface of the medium (Table 1) at rates equivalent to $3.2 \mathrm{~g} \mathrm{Mn/container.} \mathrm{Seven} \mathrm{rep-}$ licate plants were also sprayed to runoff with single foliar sprays of the materials (Table 1) at concentrations equivalent to $1.3 \mathrm{~g} \mathrm{Mn} /$ liter. The experiment was repeated starting 4 Jan. 1989 using 10 replicate palms per treatment (2nd year). All plants were grown under $63 \%$ shadecloth $\left(1800 \mu \mathrm{mol} \cdot \mathrm{m}^{-2} \cdot \mathrm{s}^{-1}\right.$ maximum photosynthetically active radiation) and received $\approx 10 \mathrm{~mm}$ of water daily
${ }^{\mathrm{z}}$ Used only in 2nd year when applied to container medium.

${ }^{\mathrm{y}}$ Rate $=6 \mathrm{~g} \cdot$ liter $^{-1}$.

${ }^{\mathrm{x}}$ Rate $=0.22 \mathrm{~g} \cdot \mathrm{liter}^{-1}$.

${ }^{\mathrm{w}}$ Rate $=1 \mathrm{ml} \cdot$ liter $^{-1}$; used only in 2nd-year experiment. from overhead irrigation. All pots received surface applications of Osmocote 17N-3P15K (Grace-Sierra, Milpitas, Calif.) at $56 \mathrm{~g} /$ pot and a single micronutrient drench containing $0.6 \mathrm{mg} \mathrm{Fe}, 0.2 \mathrm{mg} \mathrm{B}, 0.06 \mathrm{mg} \mathrm{Zn}$, $0.06 \mathrm{mg} \mathrm{Cu}$, and $0.01 \mathrm{mg} \mathrm{Mo}$ and were arranged in a completely randomized design. Samples of central leaflets of recently matured leaves were collected from each plant $1,2,4$, and 6 months after fertilization the first year and 2, 4, and 6 months after fertilization for the 2 nd year. All leaves sampled for analysis had emerged subsequent to any foliar spray treatment and, therefore, were not washed before analysis. Dried and ground leaf samples were digested in sulfuric acid and hydrogen peroxide (Allen, 1974) and analyzed for total Mn content by atomic absorption spectrophotometry. Data were tested by analysis of variance with mean separations by the Wailer-Duncan k-ratio method.

To determine if results from the container experiments would be valid for field-grown palms, a 2-year-old field planting of 50- to 60-cm-tall pygmy date palms was treated on 4 Jan. 1989 with single soil applications of the same materials used in the first container experiment. These palms were growing in a Margate fine sand soil and planted $3 \mathrm{~m}$ apart in rows of $4 \mathrm{~m}$ apart. Treatments were assigned on a completely randomized basis with nine replicate palms per treatment. Rates were $32 \mathrm{~g}$ of $\mathrm{Mn}$ and $550 \mathrm{~g}$ of Osmocote $17 \mathrm{~N}-$ 3P-15K per plant. Sampling and analysis were carried out as in the first container experiment.

Application to medium-firs year. Only Mn sulfate plus ammonium sulfate had significantly increased leaf Mn 1 month after its application to the medium, but both $\mathrm{Mn}$ sulfate plus ammonium sulfate and Mn citrate-treated palms had higher leaf Mn concentrations than control palms at 2, 4, and 6 months after treatment (Table 2). Manganese sulfate plus ammonium sulfate also in-

Table 1. Manganese fertilizer materials used for soil applications on pygmy date palms.

\begin{tabular}{|c|c|c|c|}
\hline Material & Trade name & Manufacturer & $\% \mathrm{Mn}$ \\
\hline \multicolumn{4}{|l|}{ Soil application } \\
\hline Mn oxide & Granusol & American Minerals & 40 \\
\hline $\begin{array}{l}\text { Mn sulfate } \\
\text { Mn sulfate }\end{array}$ & Mn sulfate & Mallinckrodt & 33 \\
\hline+ ammonium sulfate & Tecmangam & Eastman Chemical & \\
\hline Mn EDTA & Sequestrene Mn & CIBA-GEIGY & $\begin{array}{l}27 \\
12\end{array}$ \\
\hline Sulfur + Mn sulfate & Disper-Sul + Mn & Chemical Enterprises & $\begin{array}{r}12 \\
5\end{array}$ \\
\hline Mn citrate & Micro-Green & Liquid Ag Systems & $\begin{array}{l}3 \\
5\end{array}$ \\
\hline \multicolumn{4}{|l|}{ Foliar application } \\
\hline Mn sulfate & & Mallinckrodt & 32 \\
\hline+ ureay & & Mallinckrodt & 32 \\
\hline+ urea $^{y}+$ calcium hydroxide ${ }^{x}$ & & Mallinckrodt & 32 \\
\hline + calcium hydroxide ${ }^{x}$ & & Mallinckrodt & 32 \\
\hline$+\mathrm{DMSO}^{\mathrm{w}}$ & & Mallinckrodt & 32 \\
\hline Mn citrate & & Mallinckrodt & 30 \\
\hline+ ureay $^{y}$ & & Mallinckrodt & 30 \\
\hline Mn EDTA & Sequestrene Mn & CIBA-GEIGY & 12 \\
\hline+ urea $^{y}$ & Sequestrene $\mathrm{Mn}$ & CIBA-GEIGY & 12 \\
\hline Mn glucoheptanate & Keyplex 250 & Morse Enterprises & 1.1 \\
\hline+ ureay $^{y}$ & Keyplex 250 & Morse Enterprises & 1.1 \\
\hline
\end{tabular}


Table 2. Foliar Mn concentrations of container-grown pygmy date palms treated with various $\mathrm{Mn}$ fertilizers applied to the growing medium.

\begin{tabular}{|c|c|c|c|c|c|c|c|}
\hline \multirow[b]{4}{*}{ Material } & \multicolumn{7}{|c|}{ Mn concn $\left(\mu g \cdot g^{-1}\right)$} \\
\hline & \multicolumn{4}{|c|}{ First year } & \multicolumn{3}{|c|}{ 2nd year } \\
\hline & \multicolumn{7}{|c|}{ Months after treatment } \\
\hline & 1 & 2 & 4 & 6 & 2 & 4 & 6 \\
\hline Control & 46 & 54 & 81 & 71 & 51 & 62 & 38 \\
\hline Mn oxide & 30 & 43 & 53 & 60 & 43 & 63 & 59 \\
\hline \multicolumn{8}{|l|}{ Mn sulfate +} \\
\hline ammonium sulfate & 148 & 149 & 177 & 122 & 1308 & 1308 & 505 \\
\hline Sulfur + Mn sulfate & 27 & 39 & 55 & 74 & 131 & 225 & 498 \\
\hline Mn citrate & 70 & 110 & 134 & 143 & 830 & 1069 & 717 \\
\hline Mn EDTA & 61 & 85 & 70 & 73 & 136 & 151 & 127 \\
\hline Mn sulfate & $\ldots$ & $\ldots$ & -- & --- & 1095 & 1800 & 838 \\
\hline $\mathrm{MSD}_{0.05}$ & 43 & 36 & 42 & 43 & 66 & 58 & 31 \\
\hline
\end{tabular}

Table 3. Foliar Mn concentrations of field-grown pygmy date palms treated with various soil-applied Mn fertilizers.

\begin{tabular}{llcrr}
\hline \hline & \multicolumn{4}{c}{ Mn concn $\left(\mu \mathrm{g} \cdot \mathrm{g}^{-1}\right)$} \\
\cline { 2 - 5 } Material & \multicolumn{4}{c}{ Months after treatment } \\
\cline { 2 - 5 } & 1 & 2 & 4 & 6 \\
\hline Control & 28 & 39 & 50 & 62 \\
Mn oxide & 83 & 68 & 85 & 81 \\
Mn sulfate + & 83 & 233 & 436 & 356 \\
ammonium sulfate & & & & 95 \\
Sulfur + Mn sulfate & 50 & 56 & 81 & 98 \\
Mn citrate & 38 & 94 & 105 & 93 \\
Mn EDTA & 86 & 112 & 194 & 138 \\
MSD $_{0.05}$ & NS & & &
\end{tabular}

Table 4. Foliar Mn concentrations of container-grown pygmy date palms treated with various foliarapplied Mn fertilizers.

\begin{tabular}{|c|c|c|c|c|c|c|c|}
\hline \multirow[b]{4}{*}{ Material } & \multicolumn{7}{|c|}{ Mn concn $\left(\mu \mathrm{g} \cdot \mathrm{g}^{-1}\right)$} \\
\hline & \multicolumn{4}{|c|}{ First year } & \multicolumn{3}{|c|}{ 2nd year } \\
\hline & \multicolumn{7}{|c|}{ Months after treatment } \\
\hline & 1 & 2 & 4 & 6 & 2 & 4 & 6 \\
\hline Control & 46 & 54 & 81 & 71 & 45 & 59 & 38 \\
\hline Mn glucoheptanate & 61 & 73 & 92 & 91 & 53 & 76 & 48 \\
\hline+ urea & 43 & 43 & 51 & 46 & 44 & 58 & 48 \\
\hline Mn EDTA & 35 & 50 & 51 & 67 & 35 & 56 & 54 \\
\hline+ urea & 36 & 51 & 64 & 78 & 45 & 75 & 51 \\
\hline Mn citrate & 82 & 95 & 103 & 101 & 39 & 68 & 60 \\
\hline+ urea & 65 & 70 & 81 & 83 & 41 & 57 & 47 \\
\hline Mn sulfate & 222 & 116 & 118 & 100 & 42 & 78 & 63 \\
\hline + urea & 102 & 81 & 83 & 90 & 42 & 73 & 50 \\
\hline+ calcium hydroxide & 149 & 90 & 59 & 50 & 42 & 75 & 48 \\
\hline $\begin{array}{l}+ \text { urea }+ \\
\text { calcium hydroxide }\end{array}$ & 156 & 135 & 110 & & & & \\
\hline+ DMSO & 150 & 130 & 119 & 100 & $\begin{array}{l}30 \\
45\end{array}$ & $\begin{array}{l}14 \\
80\end{array}$ & $\begin{array}{l}52 \\
56\end{array}$ \\
\hline $\mathrm{MSD}_{0,05}$ & 39 & 39 & 32 & 41 & 11 & 4 & 4 \\
\hline
\end{tabular}

creased leaf Mn concentrations significantly more than Mn citrate after 2 and 4 months, but the differences were nonsignificant 6 months after treatment.

Application to medium-2nd year. All materials except Mn oxide had increased leaf Mn concentrations at 2, 4, and 6 months, but Mn sulfate, Mn sulfate plus ammonium sulfate, and $\mathrm{Mn}$ citrate-treated palms had much higher Mn concentrations (Table 2). Manganese concentrations of palms in medium treated with most materials began decreasing at 6 months, but continued to increase in sulfur plus Mn sulfate-treated palms. All of the materials except $\mathrm{Mn}$ oxide are water soluble and some decrease in availability is expected over time due to microbial binding or precipitation. Elemental sulfur constitutes $80 \%$ of the sulfur plus Mn sulfate material and thus would be expected to gradually decrease medium $\mathrm{pH}$ and increase Mn solubility (Ridder et al., 1990). The large differences in Mn uptake between years for similar materials can only be accounted for by the lower average ambient temperatures during the first year $6=22.4$ vs. $24.2 \mathrm{C}$ ). Manganese uptake in palms is strongly temperature dependent (Broschat and Donselman, 1985b).

Soil application-field-grown palms. No significant differences were observed among treatments after 1 month (Table 3). However, Mn concentrations in palms treated with
Mn sulfate plus ammonium sulfate were significantly higher than those of all other treatments 2 to 6 months following application. Thus, results under field conditions confirm the superior effectiveness of Mn sulfate in providing $\mathrm{Mn}$ to palms compared to other commercially available Mn sources. Similar results were obtained for field crops on other soil types (Fiskel and Mourkides, 1955; Randall et al., 1975; Shuman et al., 1979; Wilcox and Cantliffe, 1969). The pH of the field soil was higher than that of the container medium (7.25 vs. 6.45), and this likely decreased Mn availability (Lindsay, 1972). However, acidifying materials, such as sulfur plus Mn sulfate, did not improve palm Mn uptake under alkaline field soil conditions as predicted from Messenger and Hruby's (1990) work on Mn deficiency in red maple (Acer rubrum L.).

Foliar application-first year. Only $\mathrm{Mn}$ sulfate significantly increased leaf Mn concentrations over that of control plants after 1 month, but Mn citrate also did 2 months after application (Table 4). Foliar Mn concentrations in palms sprayed with Mn sulfate gradually decreased or stayed the same during the period between the first and 6th month, but no significant differences existed among treatments after 6 months. Plant uptake from foliar sprays was not enhanced by addition of calcium hydroxide or urea for any $\mathrm{Mn}$ source throughout the experiment.

Foliar application-2nd year. Leaf $\mathrm{Mn}$ concentration after 2 months was not significantly increased by foliar application of any Mn source, but palms in all treatments, except those sprayed with Mn glucoheptanate plus urea, Mn EDTA, and Mn citrate plus urea, had higher leaf Mn concentrations after 4 months than the control palms (Table 4). Palms in all treatments had higher foliar Mn concentrations than the controls after 6 months. The addition of urea enhanced $\mathrm{Mn}$ uptake only from Mn EDTA after 4 months and addition of both calcium hydroxide and urea or DMSO did not improve plant uptake of foliar-applied Mn sulfate at any time.

These results appear contrary to those reported by Yamada et al. (1965) and Labanauskas and Puffer (1964), but in those studies, urea increased Mn uptake in leaves that had been sprayed. However, the latter study also examined the effects of urea on Mn concentrations in leaves produced subsequent to spraying and reported no significant increases in Mn concentration of the new leaves due to urea application. This result is consistent with those from the current study in which only new leaves were sampled. Although foliar fertilization is generally considered to be a quicker, though short-term, method of getting micronutrients into plants, this study suggests that uptake from soil applications is just as fast, even under slightly alkaline field soil conditions.

In conclusion, of the various commercially available $\mathrm{Mn}$ fertilizer sources, Mn sulfate plus ammonium sulfate (Tecmangam) was the most effective material for soil or foliar fertilization of pygmy date palms, both in a container medium and in a slightly 
alkaline sandy field soil. Manganese citrate is moderately effective for both container medium and foliar applications, but all other materials tested were relatively ineffective as soil-applied fertilizers and produced inconsistent responses when applied to the foliage of palms. Also, there appears to be no advantage to adding calcium hydroxide, urea, or DMSO to Mn foliar sprays on palms.

\section{Literature Cited}

Allen, S.E. (ed.). 1974. Chemical analysis of ecological materials. Blackwell Scientific Publishers, Oxford, England.

Broschat, T.K. 1991. Physiological disorders, p. 33-48. In: A.R. Chase and T.K. Broschat (eds.). Diseases and disorders of ornamental palms. Amer. Phytopathol. Soc. Press. St. Paul.

Broschat, T.K. and H.M. Donselman. 1985a. Extractable $\mathrm{Mg}, \mathrm{Fe}, \mathrm{Mn}, \mathrm{Zn}$, and $\mathrm{Cu}$ from a peatbased container medium amended with various micronutrient fertilizers. J. Amer. Soc. Hort. Sci. 110:196-200.
Broschat, T.K. and H.M. Donselman. 1985b. Causes of palm nutritional disorders. Proc. Fla. State Hort. Soc. 98:101-102.

Dickey, R.D. 1977. Nutritional deficiencies of woody ornamental plants used in Florida landscapes. Univ. Florida Agr. Res. Bul. 791.

Fiskel, J.G. and G.A. Mourkides. 1955. A comparison of manganese sources using tomato plants grown on marl, peat, and sand soils. Plant \& Soil 6:313-331.

Kidder, G., M.J. Holsinger, and T.H. Yeager. 1990. Lowering of calcareous soil $\mathrm{pH}$ in fieldgrow containers. J. Environ. Hort. 8:1-4.

Labanauskas, C.K. and R.E. Puffer. 1964. Effects of foliar applications of manganese, zinc, and urea on Valencia orange yield and foliar composition. Proc. Amer. Soc. Hort. Sci. $84: 158-164$

Lindsay, W.L. 1972. Inorganic phase equilibria of micronutrients in soils, p. 41-57. In: J.J. Mortvedt, P.M. Giordano, and W.L. Lindsay (eds.). Micronutrients in agriculture. Soil Sci. Soc. Amer., Madison, Wis.
Messenger, A.S. and B.A. Hruby. 1990. Response of interveinally chlorotic red maple trees treated with Medicaps or by soil acidification. J. Environ. Hort. 8:5-9.

Randall, G.W., E.E. Schulte, and R.B. Corey. 1975. Effect of soil and foliar-applied manganese on the micronutrient content and yield of soybeans. Agron. J. 67:502-507.

Shuman, L.M., F.C. Boswell, K. Ohki, M.B Parker, and D.O. Wilson. 1979. soybean yield, leaf manganese, and soil manganese as affected by sources and rates of manganese and soil $\mathrm{pH}$. Agron. J. 71:989-991.

Wilcox, G.E. and D.J. Cantliffe. 1969. Plant response to manganese source, rate and method of application. J. Amer. Soc. Hort. Sci. 94:354356

Yamada, Y., W.H. Jyung, S.H. Wittwer, and M.J. Bukovac. 1965. The effects of urea on ion penetration through isolated cuticular membranes and ion uptake by leaf cells. Proc. Amer. Soc. Hort. Sci. 87:429-432. 